\title{
A Raman spectroscopic study of the arsenate mineral chenevixite $\mathrm{Cu}_{2} \mathrm{Fe}_{2}^{3+}\left(\mathrm{AsO}_{4}\right)_{2}(\mathrm{OH})_{4} \cdot \mathrm{H}_{2} \mathrm{O}$
}

\author{
Ray L. Frost ${ }^{\mathrm{a}, *}$, Andrés López ${ }^{\mathrm{a}}$, Ricardo Scholz ${ }^{\mathrm{b}}$, Cristiano Lana ${ }^{\mathrm{b}}$, Yunfei Xi ${ }^{\mathrm{a}}$

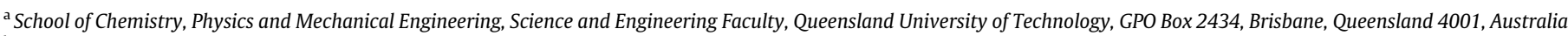 \\ ${ }^{\mathrm{b}}$ Geology Department, School of Mines, Federal University of Ouro Preto, Campus Morro do Cruzeiro, Ouro Preto, MG 35,400-00, Brazil
}

\section{H I G H L I G H T S}

- We have studied the mineral chenevixite from Chile.

- Using a combination of SEM with EDX and vibrational spectroscopy.

- Qualitative chemical analysis shows a homogeneous composition, with As, $\mathrm{Fe}, \mathrm{Al}, \mathrm{Cu}, \mathrm{Fe}$ and $\mathrm{Cu}$.

- Characteristic Raman bands of $\mathrm{AsO}_{4}^{3-}$ stretching and bending vibrations are identified.

\section{G R A P H I C A L A B S T R A C T}

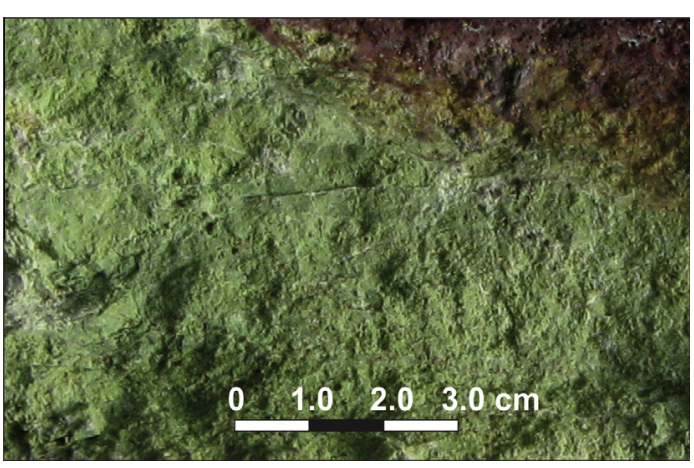

\begin{abstract}
A B S T R A C T
We have studied the mineral chenevixite from Manto Cuba Mine, San Pedro de Cachiyuyo District, Inca de Oro, Chañaral Province, Atacama Region, Chile, using a combination of scanning electron microscopy (SEM) with energy dispersive spectroscopy (EDX) and vibrational spectroscopy. Qualitative chemical analysis shows a homogeneous composition, with predominance of $\mathrm{As}, \mathrm{Fe}, \mathrm{Al}, \mathrm{Cu}, \mathrm{Fe}$ and $\mathrm{Cu}$. Minor amounts of Si were also observed. Raman spectroscopy complimented with infrared spectroscopy has been used to assess the molecular structure of the arsenate minerals chenevixite. Characteristic Raman and infrared bands of the $\left(\mathrm{AsO}_{4}\right)^{3-}$ stretching and bending vibrations are identified and described. The observation of multiple bands in the $\left(\mathrm{AsO}_{4}\right)^{3-}$ bending region offers support for the loss of symmetry of the arsenate anion in the structure of chenevixite. Raman bands attributable to the OH stretching vibrations of water and hydroxyl units were analysed. Estimates of the hydrogen bond distances were made based upon the $\mathrm{OH}$ stretching wavenumbers.
\end{abstract}

(c) 2014 Elsevier B.V. All rights reserved.

\section{Introduction}

There exists a large number of darkish emerald green copper arsenate minerals [1,2], including chenevixite $\mathrm{Cu}_{2} \mathrm{Fe}_{2}^{3+}\left(\mathrm{AsO}_{4}\right)_{2}$ $(\mathrm{OH})_{4}$, chalcophyllite $\mathrm{Cu}_{18} \mathrm{Al}_{2}\left(\mathrm{AsO}_{4}\right)_{4}\left(\mathrm{SO}_{4}\right)_{3}(\mathrm{OH})_{24} \cdot 36 \mathrm{H}_{2} \mathrm{O}$ and

\footnotetext{
* Corresponding author. Tel.: +61 73138 2407; fax: +61 731381804

E-mail address: r.frost@qut.edu.au (R.L. Frost).
}

euchroite $\mathrm{Cu}_{2}\left(\mathrm{AsO}_{4}\right)(\mathrm{OH}) \cdot 3 \mathrm{H}_{2} \mathrm{O}$ [3-5]. The color of the mineral will vary according to the ratio of $\mathrm{Fe}$ to $\mathrm{Al}$ in the mineral, but is always a bright dark green color. The mineral occurs in the oxidized zones of copper deposits with olivenite $\mathrm{Cu}_{2}\left(\mathrm{AsO}_{4}\right)(\mathrm{OH})$, is the most common mineral. The mineral chenevixite was often written as $\mathrm{Cu}_{2} \mathrm{Fe}_{2}^{3+}$ $\left(\mathrm{AsO}_{4}\right)_{2}(\mathrm{OH})_{4} \cdot \mathrm{H}_{2} \mathrm{O}$. The work of burns et al. showed that the mineral contained no water [6] i.e. the correct formula is $\mathrm{Cu}_{2} \mathrm{Fe}_{2}^{3+}$ $\left(\mathrm{AsO}_{4}\right)_{2}(\mathrm{OH})_{4}$. Another mineral of a comparative formula is luetheite $\mathrm{Cu}_{2} \mathrm{Al}_{2}^{3+}\left(\mathrm{AsO}_{4}\right)_{2}(\mathrm{OH})_{4} \cdot \mathrm{H}_{2} \mathrm{O}$. 
The relative stabilities of the basic copper arsenates have been determined using estimated chemical parameters and experimentally determined solubility products $[7,8]$. The more basic stoichiometries occupy fields at higher $\mathrm{pH}$ as expected. Olivenite is the stable phase under chemical conditions intermediate to those that serve to stabilise cornwallite and clinoclase and paragenetic relationships have been explored [9]. The more basic stoichiometries occupy fields at higher $\mathrm{pH}$ as expected. Williams [10] has presented phase stability relationships between a range of diagenetically related minerals including the basic copper arsenates. Magalhães et al. [10] reported the relative stabilities of the basic copper arsenates using estimated chemical parameters and experimentally determined solubility products [6,7]. The difference in stability is attributed to $\mathrm{pH}$, temperature of crystallization and the relative redox potentials.

Chenevixite is a secondary mineral formed in the oxidized zones of some arsenic bearing multimetallic deposits [11]. It is known from more than 100 sites worldwide. The mineral has a monoclinic structure [12] and the structure has been known for a long period of time [13-16]. The crystal structure of chenevixite, $\mathrm{Cu}_{2} \mathrm{M}_{2}\left(\mathrm{AsO}_{4}\right)_{2}(\mathrm{OH})_{4}$ (where $\mathrm{M}=\mathrm{Fe} 3+$ or $\mathrm{Al}$ ), pseudo-orthorhombic monoclinic, $a=5.7012(8) \AA, b=5.1801(7) \AA, c=29.265(2) \AA$ [6]. The composition of the mineral remained a challenge for a long time as the amount of water in the structure was difficult to determine $[17,18]$. Burns et al. showed that the mineral contained no water at all [6]. Ross [19] in Farmer's treatise reported the infrared spectrum of selected arsenate minerals. However, the Raman spectra have not been forthcoming. Only two prominent infrared features were observed by Ross for arsenate bearing minerals: a band at $815 \mathrm{~cm}^{-1}$ assigned to $\mathrm{AsO}_{4}^{3-}$ and a band at $1100 \mathrm{~cm}^{-1}$ ascribed to $\mathrm{SO}_{4}^{2-}$ vibrations.

Raman spectroscopy has proven most useful for the study of secondary minerals. The aim of this paper is to report the vibrational spectra of chenevixite and to relate the spectra to the molecular structure of this arsenate mineral. The paper follows the systematic research on Raman and infrared spectroscopy of secondary minerals containing oxy-anions formed in the oxidation zone.

\section{Experimental}

Samples description and preparation

The chenevixite sample studied in this work forms part of the collection of the Geology Department of the Federal University of Ouro Preto, Minas Gerais, Brazil, with sample code SAC-196. The mineral origin is from the Manto Cuba Mine, San Pedro de Cachiyuyo District, Inca de Oro, Chañaral Province, Atacama Region, Chile. The studied sample occurs in association with Fe oxides/hydroxides. A photo of the chenevixite is given in the graphical abstract.

The mineral sample was gently crushed and the associated minerals were removed under a stereomicroscope Leica MZ4. The chenevixite studied in this work occurs as single crystals with prismatic hexagonal form up to $0.5 \mathrm{~mm}$. Scanning electron microscopy (SEM) in the EDS mode was applied to support the mineral characterization.

\section{Scanning electron microscopy (SEM)}

Experiments and analyses involving electron microscopy were performed in the Center of Microscopy of the Universidade Federal de Minas Gerais, Belo Horizonte, Minas Gerais, Brazil (http:// www.microscopia.ufmg.br).

Chenevixite crystals were coated with a $5 \mathrm{~nm}$ layer of evaporated carbon. Secondary Electron and Backscattering Electron images were obtained using a JEOL JSM-6360LV equipment.
Qualitative and semi-quantitative chemical analyses in the EDS mode were performed with a ThermoNORAN spectrometer model Quest and was applied to support the mineral characterization.

\section{Raman microprobe spectroscopy}

Crystals of chenevixite were placed on a polished metal surface on the stage of an Olympus BHSM microscope, which is equipped with $10 \times, 20 \times$, and $50 \times$ objectives. The microscope is part of a Renishaw 1000 Raman microscope system, which also includes a monochromator, a filter system and a CCD detector (1024 pixels). The Raman spectra were excited by a Spectra-Physics model 127 He-Ne laser producing highly polarized light at $633 \mathrm{~nm}$ and collected at a nominal resolution of $2 \mathrm{~cm}^{-1}$ and a precision of $\pm 1 \mathrm{~cm}^{-1}$ in the range between 100 and $4000 \mathrm{~cm}^{-1}$. The power at the sample was $0.1 \mathrm{~mW}$. It is important to use low power so that the mineral is not degraded. Repeated acquisitions on the crystals using the highest magnification $(50 \times)$ were accumulated to improve the signal to noise ratio of the spectra. Raman Spectra were calibrated using the $520.5 \mathrm{~cm}^{-1}$ line of a silicon wafer. The Raman spectrum of at least 10 crystals was collected to ensure the consistency of the spectra.

A Raman spectrum of chenevixite downloaded from the RRUFF data base is given in the supplementary information as Figs. S1 and S2.

\section{Infrared spectroscopy}

Infrared spectra were obtained using a Nicolet Nexus 870 FTIR spectrometer with a smart endurance single bounce diamond ATR cell. Spectra over the $4000-525 \mathrm{~cm}^{-1}$ range were obtained by the co-addition of 128 scans with a resolution of $4 \mathrm{~cm}^{-1}$ and a mirror velocity of $0.6329 \mathrm{~cm} / \mathrm{s}$. Spectra were co-added to improve the signal to noise ratio.

Spectral manipulation such as baseline correction/adjustment and smoothing were performed using the Spectracalc software package GRAMS (Galactic Industries Corporation, NH, USA). Band component analysis was undertaken using the Jandel 'Peakfit' software package that enabled the type of fitting function to be selected and allows specific parameters to be fixed or varied accordingly. Band fitting was done using a Lorentzian-Gaussian cross-product function with the minimum number of component bands used for the fitting process. The Lorentzian-Gaussian ratio was maintained at values greater than 0.7 and fitting was undertaken until reproducible results were obtained with squared correlations of $r^{2}$ greater than 0.995 .

\section{Results and discussion}

\section{Chemical characterization}

The SEM image of chenevixite sample studied in this work is shown in Fig. 1. The image shows a fragment of a crystal aggregate. Semi-quantitative chemical analysis shows a homogeneous composition, with predominance of $\mathrm{As}, \mathrm{Fe}, \mathrm{Al}$, and $\mathrm{Cu}$. Minor amounts of Si were also observed. The chemical analysis is shown in Fig. 2. The formula of the studied mineral is $\mathrm{Cu}_{2}\left(\mathrm{Fe}_{1.75}^{3+}\right.$, $\left.\mathrm{Al}_{0,25}\right)_{\sum 2.00}\left(\mathrm{AsO}_{4}\right)_{2}(\mathrm{OH})_{4}$.

\section{Spectroscopy}

\section{Background}

The vibrational modes of oxyanions in aqueous systems are well known. The symmetric stretching vibration of the arsenate 


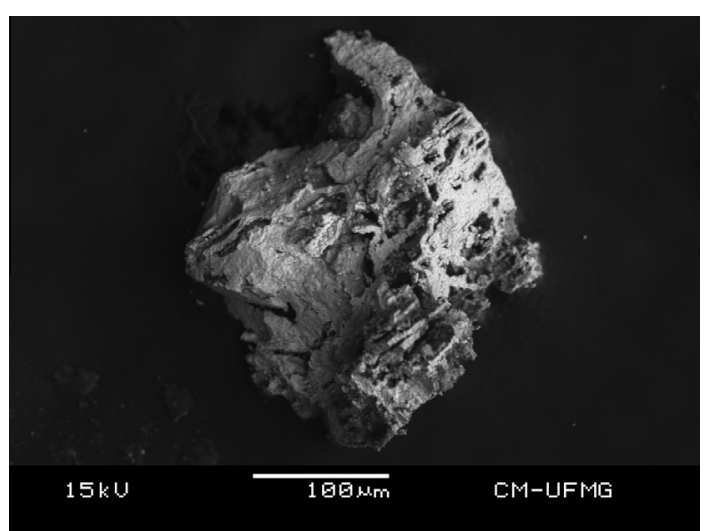

Fig. 1. Shows a backscattered electron image (BSI) of a chenevixite aggregate up to $0.5 \mathrm{~mm}$ in length.

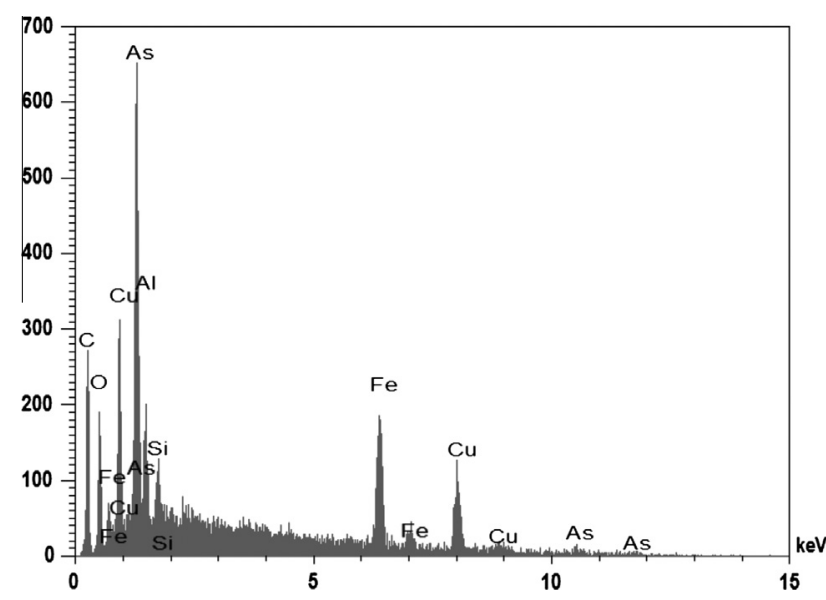

Fig. 2. EDS analysis of chenevixite.

anion $\left(v_{1}\right)$ is observed at $810 \mathrm{~cm}^{-1}$ and may coincide with the position of the antisymmetric stretching mode $\left(v_{3}\right)$. The symmetric bending mode $\left(v_{2}\right)$ is observed at $342 \mathrm{~cm}^{-1}$ and the antisymmetric bending mode $\left(v_{4}\right)$ at $398 \mathrm{~cm}^{-1}$. The positions of the arsenate vibrations occur at lower wavenumbers than any of the other naturally occurring oxyanions. Farmer lists a number of infrared spectra of arsenates including roselite, annabergite, erythrite, symplesite and köttigite [18]. The effect of reduced site symmetry in the crystal (compared with the free arsenate ion) will remove the degeneracy and allow splitting of the bands according to factor group analysis. Farmer based upon the work of Moenke reported the infrared spectra of roselite [19]. Farmer listed two bands at 985 and $920 \mathrm{~cm}^{-1}$ and assigned these bands to the $v_{1}\left(\mathrm{AsO}_{4}\right)^{2-}$ symmetric stretching vibrations [18]. The $\mathrm{v}_{3}\left(\mathrm{AsO}_{4}\right)^{2-}$ symmetric stretching vibrations were listed as 870,850 and $805 \mathrm{~cm}^{-1}$. The assignment of these bands is questionable. The $v_{4}$ bending modes were found at 453 and $435 \mathrm{~cm}^{-1}$. No $v_{2}$ bands were shown. A band at $535 \mathrm{~cm}^{-1}$ was not assigned but may well be attributed to a water libration mode. No $\mathrm{OH}$ stretching vibrations were listed. For comparison Farmer listed the $v_{1}$ and $v_{3}$ bands of annabergite at $832 \mathrm{~cm}^{-1}$ and $795 \mathrm{~cm}^{-1}$. The $v_{4}$ bending modes were found at 510,460 and $427 \mathrm{~cm}^{-1}$ for annabergite. Two $\mathrm{OH}$ stretching vibrations were observed at 3430 and $3160 \mathrm{~cm}^{-1}$ for annabergite. A number of bands were listed which were unassigned.

Few comprehensive studies of the fairfieldite and roselite mineral subgroups and related minerals such as divalent cationic arsenates have been undertaken [19]. Most of the infrared data predates the advent of Fourier transform infrared spectroscopy
[20-25]. Although some Raman studies of some arsenate minerals have been undertaken [26,27], no Raman spectroscopic investigation of arsenate mineral chenevixite has been forthcoming. Griffith [27] did report the results of the Raman spectrum of a synthetic annabergite. The symmetric stretching mode of the $\left(\mathrm{AsO}_{4}\right)^{2-}$ unit was observed at $859 \mathrm{~cm}^{-1}$; the antisymmetric stretching mode at $880 \mathrm{~cm}^{-1}$, the symmetric bending mode at $438 \mathrm{~cm}^{-1}$ and antisymmetric bending mode at $452 \mathrm{~cm}^{-1}$; other bands were located at 797 and $820 \mathrm{~cm}^{-1}$ [28]. The structural investigation of some arsenates and the nature of the hydrogen bond in these structures have been undertaken. It was found that the hydroxyl unit was coordinated directly to the metal ion and formed hydrogen bonds to the arsenate anion [29]. The minerals selected for this study are fundamentally related, both in structure and composition. As part of a comprehensive study of the molecular structure of minerals containing oxyanions using IR and Raman spectroscopy, we report the Raman and infrared properties of chenevixite.

\section{Vibrational spectroscopy}

The Raman spectrum of chenevixite over the $100-4000 \mathrm{~cm}^{-1}$ spectral range is reported in Fig. 3a. This figure shows the position and relative intensities of the Raman bands. It is noted that there are large parts of the spectrum where no intensity is observed. Thus, the spectrum is subdivided into sections based upon the type of vibration being examined. The infrared spectrum of chenevixite over the $500-4000 \mathrm{~cm}^{-1}$ spectral range is shown in Fig. $3 \mathrm{~b}$. This spectrum displays the peak position and relative intensities of the infrared bands. Again, there are large parts of the spectrum where no intensity is observed. The infrared spectrum is subdivided into sections based upon the type of vibration being studied.
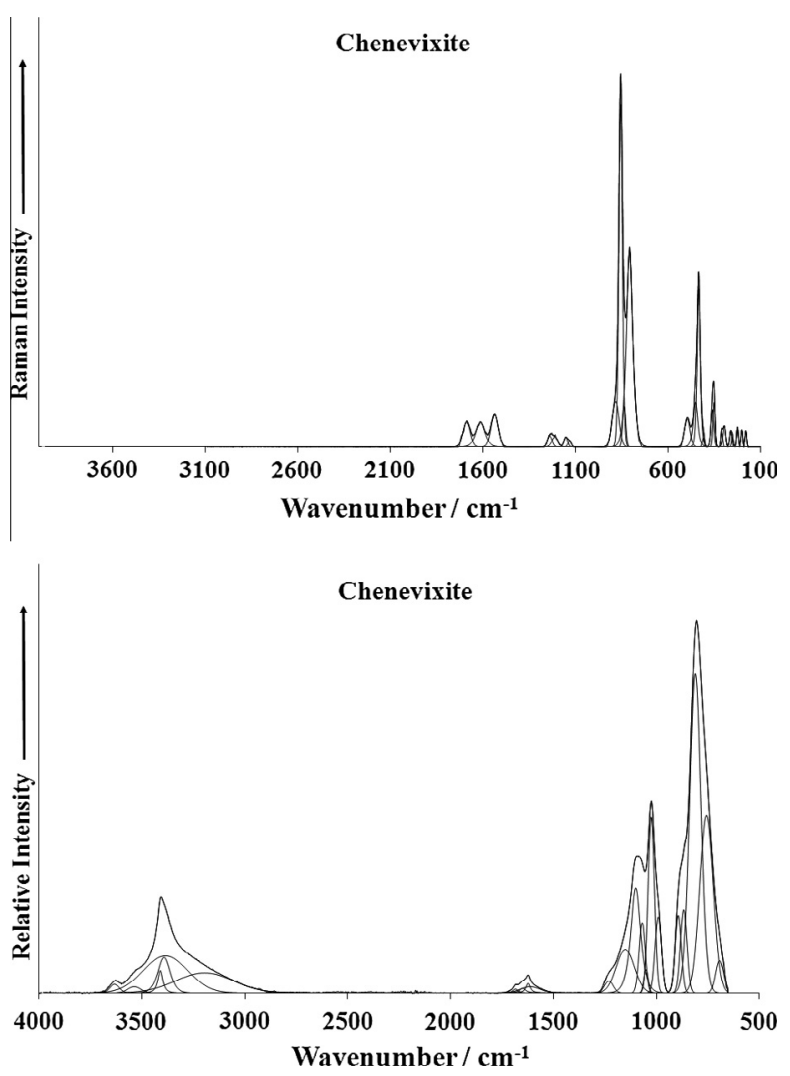

Fig. 3. (a) Raman spectrum of chenevixite (upper spectrum) over the 100$4000 \mathrm{~cm}^{-1}$ spectral range and (b) infrared spectrum of chenevixite (lower spectrum) over the $500-4000 \mathrm{~cm}^{-1}$ spectral range. 
It is noted that some significant intensity is observed over the $3000-4000 \mathrm{~cm}^{-1}$ spectral range.

The Raman spectrum of chenevixite over the $700-950 \mathrm{~cm}^{-1}$ spectral range is shown in Fig. 4a. Raman peaks are observed at 807 and $855 \mathrm{~cm}^{-1}$ with two additional bands at 806 and $883 \mathrm{~cm}^{-1}$. The Raman band at $855 \mathrm{~cm}^{-1}$ is assigned to the $\mathrm{AsO}_{4}^{3-}$ $v_{1}$ symmetric stretching mode, whereas the Raman band at $807 \mathrm{~cm}^{-1}$ is attributed to the $\mathrm{AsO}_{4}^{3-} v_{3}$ antisymmetric stretching mode. It is probable that the Raman bands at 883 and $836 \mathrm{~cm}^{-1}$ are attributable to the $v_{1}$ symmetric stretching and $v_{3}$ antisymmetric stretching modes of the $\mathrm{HOAsO}_{3}^{2-}$ units $[1,2]$.

A comparison may be made with the spectrum of chalcophyllite [1]. Raman bands are found at bands at 814 and $867 \mathrm{~cm}^{-1}$ for this mineral. The Raman spectrum of chenevixite downloaded from the RRUFF data base is given in Figs. S1 and S2. Raman bands in the RRUFF spectrum are observed at 774 and $823 \mathrm{~cm}^{-1}$. Additional bands in the RRUFF spectrum are found at 994 and $1005 \mathrm{~cm}^{-1}$. These bands may probably be ascribed to phosphate stretching modes. The position of these bands is not in agreement with this work.

The infrared spectrum of chenevixite over the $650-950 \mathrm{~cm}^{-1}$ spectral range is illustrated in Fig. $4 \mathrm{~b}$. This infrared spectrum does not show the band separation of the Raman spectrum. An infrared band is found at $864 \mathrm{~cm}^{-1}$ assigned to the $\mathrm{AsO}_{4}^{3-} v_{1}$ symmetric stretching vibration and is the equivalent of the Raman band at $855 \mathrm{~cm}^{-1}$. The infrared band at $807 \mathrm{~cm}^{-1}$ assigned to the $\mathrm{AsO}_{4}^{3-}$ $v_{3}$ antisymmetric stretching mode is the infrared equivalent of the Raman band at $753 \mathrm{~cm}^{-1}$. Other infrared bands are noted at 690 and $890 \mathrm{~cm}^{-1}$. Infrared bands for chalcophyllite are observed at 810 and $818 \mathrm{~cm}^{-1}$. These bands for chalcophyllite are assigned to the $\left(\mathrm{AsO}_{4}\right)^{3-} \mathrm{v}_{3}$ and $\mathrm{v}_{1}$ antisymmetric and symmetric stretching mode.
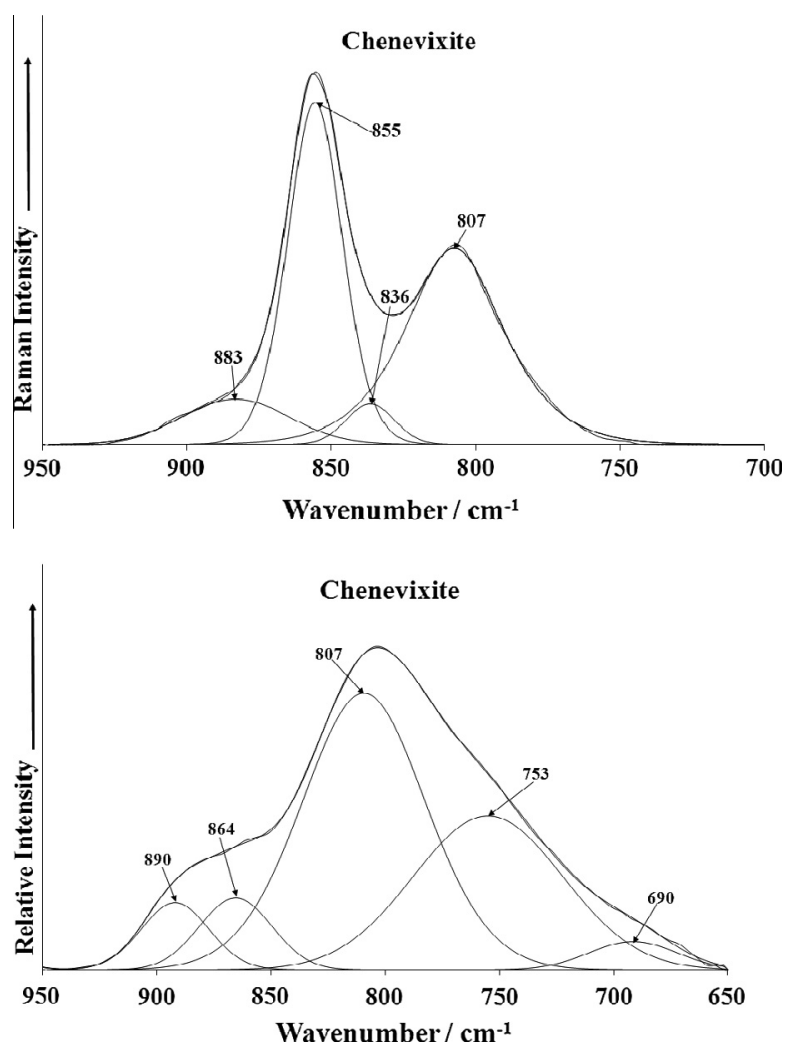

Fig. 4. (a) Raman spectrum of chenevixite (upper spectrum) in the $700-950 \mathrm{~cm}^{-1}$ spectral range and (b) infrared spectrum of chenevixite (lower spectrum) in the $650-950 \mathrm{~cm}^{-1}$ spectral range.
The Raman spectrum of chenevixite over the $300-600 \mathrm{~cm}^{-1}$ spectral range and over the $100-300 \mathrm{~cm}^{-1}$ spectral range are displayed in Fig. 5a and b. The Raman bands centred upon 433, 450 and $495 \mathrm{~cm}^{-1}$ are assigned to the $\mathrm{AsO}_{4}^{3-} \mathrm{v}_{2}$ bending mode. A comparison may be made with the Raman spectrum of chenevixite given in the RRUFF data base. In this spectrum, Raman bands are found at 413,474 and $532 \mathrm{~cm}^{-1}$. The position of these bands is at variance with this work. The observation of multiple bands in this spectral region is simply due to symmetry lowering. The Raman spectrum also shows two bands at 350 and $359 \mathrm{~cm}^{-1}$. These bands are assigned to the $\mathrm{AsO}_{4}^{3-} \mathrm{v}_{4}$ bending mode. Two Raman peaks are found at 296 and $309 \mathrm{~cm}^{-1}$. One possibility for the assignment of these bands is to $\mathrm{FeO}$ and $\mathrm{CuO}$ stretching vibrations. Raman bands of chenevixite from the RRUFF data base are found at 294 and $338 \mathrm{~cm}^{-1}$ (Fig. S1). Other Raman bands at 179, 200, 224, 251 and $261 \mathrm{~cm}^{-1}$ are simply described as external vibrations.

The Raman spectrum in the $\mathrm{OH}$ stretching region of chenevixite is displayed in Fig. 6a.

The spectral profile in the $2600-3800 \mathrm{~cm}^{-1}$ region is a complex set of overlapping bands which are due to water stretching and $\mathrm{OH}$ stretching bands. The interpretation of the overlapping bands is not easy. One model is to assume the lower wavenumber bands are due to the water stretching bands and the highest wavenumber bands to the $\mathrm{OH}$ stretching vibrations of the $\mathrm{OH}$ units. Raman bands are identified at 3315, 3405 and $3501 \mathrm{~cm}^{-1}$. These bands are assigned to water stretching vibrations.

The infrared spectrum in the $\mathrm{OH}$ stretching region of chenevixite is displayed in Fig. 6b.

Following this premise, the infrared bands at 3192, 3382, 3390, 3408 and $3534 \mathrm{~cm}^{-1}$ are assigned to water stretching vibrations. It
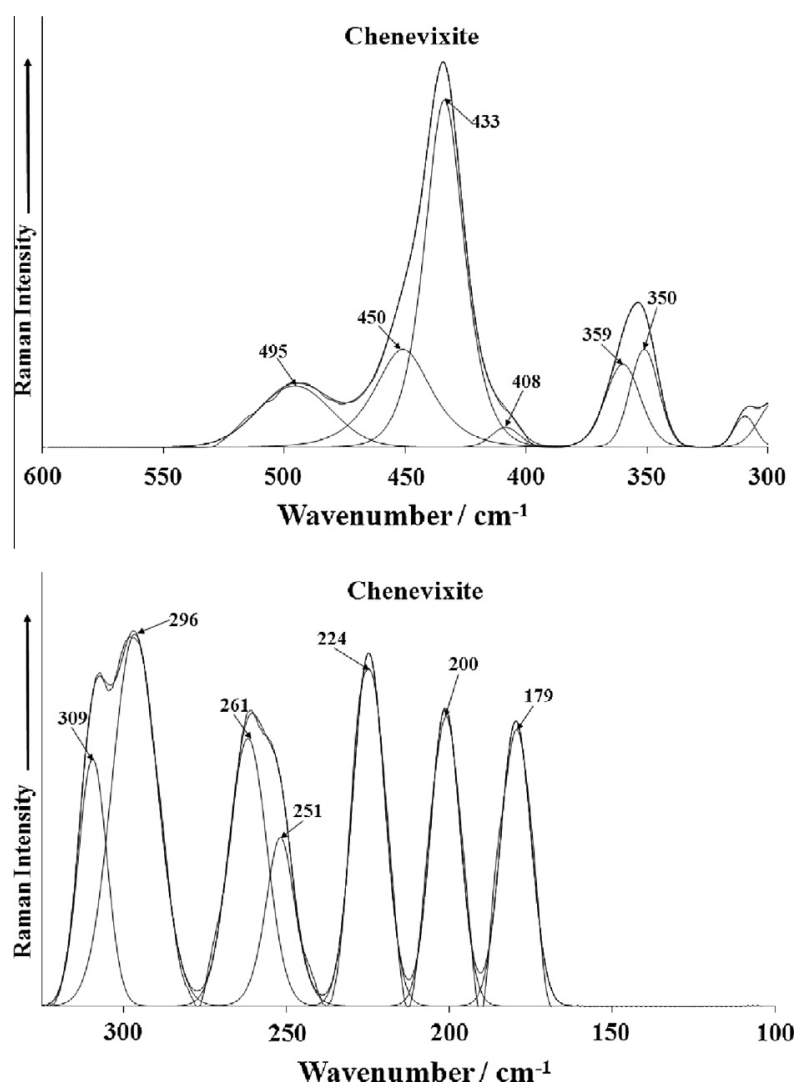

Fig. 5. (a) Raman spectrum of chenevixite (upper spectrum) in the $300-600 \mathrm{~cm}^{-1}$ spectral range and (b) Raman spectrum of chenevixite (lower spectrum) in the 100 $350 \mathrm{~cm}^{-1}$ spectral range. 

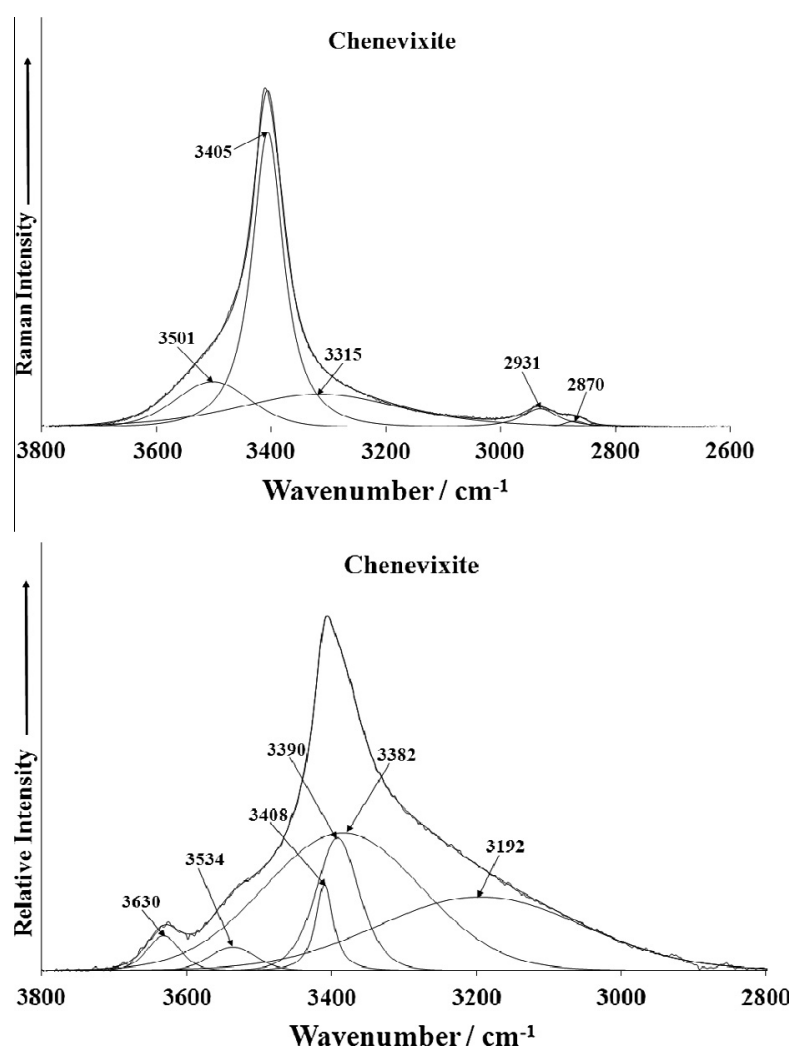

Fig. 6. (a) Raman spectrum of chenevixite in the $2600-3800 \mathrm{~cm}^{-1}$ spectral range and (b) infrared spectrum of chenevixite in the $2800-3800 \mathrm{~cm}^{-1}$ spectral range.

is noted that there are two bands in the Raman spectrum of chenevixite from the RRUFF data base (Fig. S2) at 3398 and $3710 \mathrm{~cm}^{-1}$. The first band is very broad with a long tail on the low wavenumber side. These peak wavenumbers differ from the values reported in this work.

Studies have shown a strong correlation between $\mathrm{OH}$ stretching wavenumbers and both the $\mathrm{O} \cdots \mathrm{O}$ bond distances and the $\mathrm{H} \cdots \mathrm{O}$ hydrogen bond distances [30-34]. The elegant work of Libowitzky [34] showed that a regression function can be employed relating the above correlations with regression coefficients better than 0.96 [34]. The function is $v_{1}=(3592-304) \times 109^{\frac{-d(0-O)}{0.1321}} \mathrm{~cm}^{-1}$. Two types of $\mathrm{OH}$ units are identified in the structure and the known hydrogen bond distances used to predict the hydroxyl stretching wavenumbers. Thus if we calculate the hydrogen bond distances using the Libowitzky type formula, the $3534 \mathrm{~cm}^{-1}$ band provide a hydrogen bond distance of $3.062(5) \AA$, $3390 \mathrm{~cm}^{-1}$ gives $2.766(5) \AA, 3382 \mathrm{~cm}^{-1}$ gives 2.794(1) $\AA$. The spectrum of chenevixite may be divided into two groups of $\mathrm{OH}$ stretching wavenumbers: namely $3600-3700 \mathrm{~cm}^{-1}$ and $2900-3600 \mathrm{~cm}^{-1}$. This distinction suggests that the strength of the hydrogen bonds as measured by the hydrogen bond distances can also be divided into two groups. An arbitrary cut-off point may be $2.74 \AA$ based upon the wavenumber $3300 \mathrm{~cm}^{-1}$. The hydrogen bond distances 3.062(5) $\AA$ may be described as weak hydrogen bonding and the bond distances of 2.766(5) and 2.794(1) Å as slightly stronger hydrogen bonds. Thus, by using the position of the bands in the Raman spectrum, an estimate of the hydrogen bond distances can be made. Such values are difficult to obtain from single crystal X-ray diffraction data. Hydrogen bond distances can be obtained from neutron diffraction data but such studies are very rare.

The Raman spectrum of chenevixite over the $1050-1750 \mathrm{~cm}^{-1}$ spectral range is shown in Fig. 7a. This spectrum is of a very low intensity and is only obtained by scale expanding along the Y-axis.
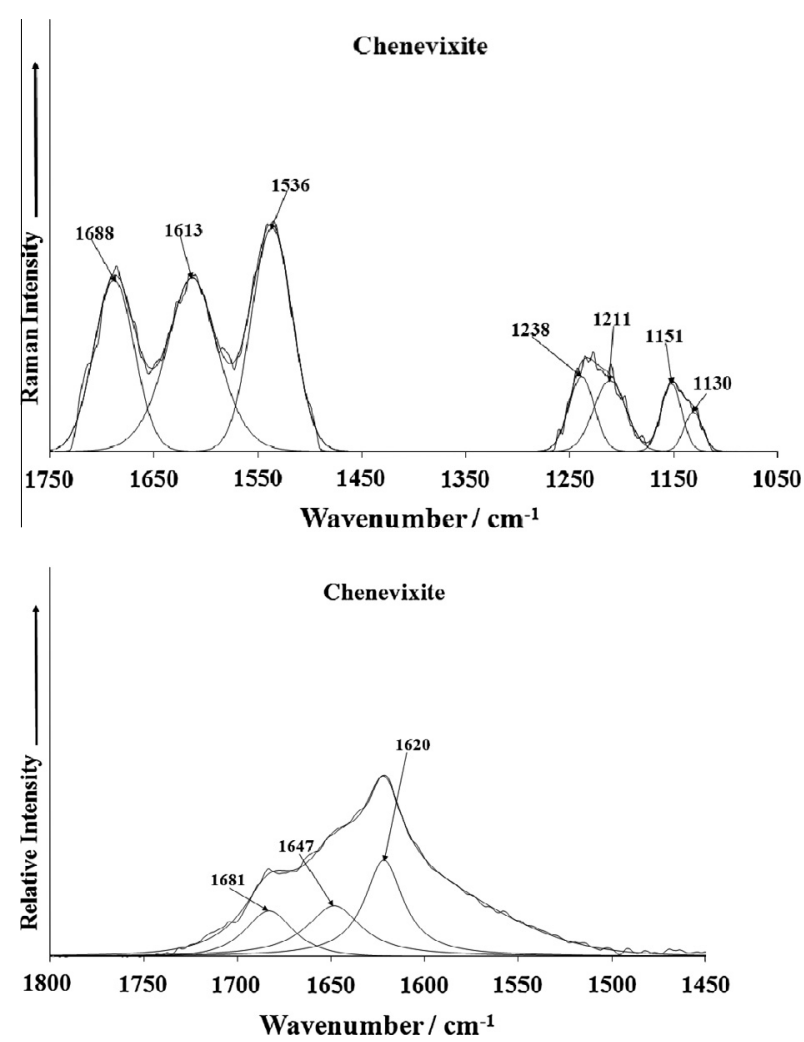

Fig. 7. (a) Raman spectrum of chenevixite (upper spectrum) in the 1050$1750 \mathrm{~cm}^{-1}$ spectral range and (b) infrared spectrum of chenevixite (lower spectrum) in the $1450-1800 \mathrm{~cm}^{-1}$ spectral range

A series of Raman bands are found at 1130, 1151, 1211 and $1238 \mathrm{~cm}^{-1}$. The assignment of these bands is not known but one possibility is that they are due to overtones of the Raman bands over the $700-950 \mathrm{~cm}^{-1}$ spectral region. A second explanation is that the bands are due to very low amounts of an impurity phase. Raman bands are also noted at 1536, 1613 and $1688 \mathrm{~cm}^{-1}$. The infrared spectrum of chenevixite over the $1450-1800 \mathrm{~cm}^{-1} \mathrm{spec}-$ tral range is reported in Fig. 7b. The spectral profile is complex with overlapping infrared bands. Infrared bands are found at 1620, 1647 and $1681 \mathrm{~cm}^{-1}$. These bands are assigned to water bending modes. The band at $1620 \mathrm{~cm}^{-1}$ is ascribed to the bending mode of liquid water, whereas, the band at $1647 \mathrm{~cm}^{-1}$ is attributed to strongly hydrogen bonded water in the structure of chenevixite and the band at $1681 \mathrm{~cm}^{-1}$ is assigned to very strongly hydrogen bonded water.

\section{Conclusions}

Raman spectroscopy has been used to characterise the molecular structure of the mineral chenevixite $\mathrm{Cu}_{2} \mathrm{Fe}_{2}^{3+}\left(\mathrm{AsO}_{4}\right)_{2}(\mathrm{OH})_{4}$. Characteristic Raman bands of the $\left(\mathrm{AsO}_{4}\right)^{3-}$ stretching and bending vibrations are identified and described. Raman bands attributable to the $\mathrm{OH}$ stretching vibrations of water and hydroxyl units were analysed. Estimates of the hydrogen bond distances were made based upon the $\mathrm{OH}$ stretching wavenumbers. A comparison was made with the Raman spectrum of chenevixite with other selected basic copper arsenate minerals.

\section{Acknowledgements}

The financial and infra-structure support of the Discipline of Nanotechnology and Molecular Science, Science and Engineering 
Faculty of the Queensland University of Technology, is gratefully acknowledged. The Australian Research Council (ARC) is thanked for funding the instrumentation. The authors would like to acknowledge the Center of Microscopy at the Universidade Federal de Minas Gerais (http://www.microscopia.ufmg.br) for providing the equipment and technical support for experiments involving electron microscopy. C. Lana thanks to CNPq (Grant 402852/ 2012-5).

\section{Appendix A. Supplementary material}

Supplementary data associated with this article can be found, in the online version, at http://dx.doi.org/10.1016/j.saa.2014.06.091.

\section{References}

[1] W. Martens, R.L. Frost, J.T. Kloprogge, P.A. Williams, J. Raman Spectrosc. 34 (2003) 145-151.

[2] R.L. Frost, W.N. Martens, P.A. Williams, J. Raman Spectrosc. 33 (2002) 475-484

[3] L.G. Berry, Am. Min. 36 (1951) 484-503.

[4] R.K. Eby, F.C. Hawthorne, Acta Crystallogr. C45 (1989) 1479-1482.

[5] F. Cech, P. Laznicka (1965) 149-155.

[6] P.C. Burns, J.V. Smith, I.M. Steele, Mineral. Mag. 64 (2000) 25-30.

[7] R. Mas, Ann. Chim. 4 (1949) 459-504.

[8] R. Mas, Compt. Rend. 227 (1948) 1245-1247.
[9] P.A. Williams, Oxide Zone Geochemistry, Ellis Horwood Ltd., Chichester, West Sussex, England, 1990.

[10] M.C.F. Magalhães, J.D. Pedrosa de Jesus, P.A. Williams, Min. Mag. 52 (1988) $679-690$.

[11] J.W. Anthony, R.A. Bideaux, K.W. Bladh, M.C. Nichols, Handbook of Mineralogy, Mineral Data Publishing, Tuscon, Arizona, USA, 1995.

[12] C. Sabelli, Zeit. Krist. 151 (1980) 129-140.

[13] A.H. Church, J. Chem. Soc. 23 (1870) 165-171.

[14] C. Guillemin, Bull. Soc. Franc. 79 (1956) 7-95.

[15] E.G.J. Hartley, Min. Mag. 12 (1899) 120-122.

[16] C. Palache, H.E. Merwin, Am. J. Sci. 28 (1910) 537.

[17] M. Piazza, Period. Min. 2 (1931) 104-121.

[18] E.V. Shannon, Am. J. Sci. 7 (1924) 31-36.

[19] V.C. Farmer, Mineralogical Society Monograph 4: The Infrared Spectra of Minerals, Mineralogical Society, London, 1974.

[20] K. Omori, T. Seki, Ganseki Kobutsu Kosho Gakkaishi 44 (1960) 7-13.

[21] S.V. Gevork'yan, A.S. Povarennykh, Konst. Svoistva Miner. 7 (1973) 92-99.

[22] S.V. Gevork'yan, A.S. Povarennykh, Mineral. Zh. 2 (1980) 29-36.

[23] G.R. Hunt, J.W. Salisbury, C.J. Lenhoff, Mod. Geol. 3 (1972) 121-132.

[24] G.R. Hunt, Geophysics 42 (1977) 501-513.

[25] R. Sitzia, Rend. Semin. Fac. Sci. Univ. Cagliari 36 (1966) 105-115.

[26] B. Piriou, J.F. Poullen, J. Raman Spectrosc. 15 (1984) 343-346.

[27] C.A. Melendres, N. Camillone III, T. Tipton, Electrochim. Acta 34 (1989) 281286.

[28] W.P. Griffith, J. Chem. Soc. A (1970) 286-291.

[29] V.I. Sumin De Portilla, Can. Min. 12 (1974) 262-268.

[30] J. Emsley, Chem. Soc. Rev. 9 (1980) 91-124.

[31] H. Lutz, Struct. Bond. 82 (1995) 85-103.

[32] W. Mikenda, J. Mol. Struct. 147 (1986) 1-15.

[33] A. Novak, Struct. Bond. 18 (1974) 177-216.

[34] E. Libowitzky, Monatsh. Chem. 130 (1999) 1047-1059. 